\title{
Nye hovedredaktører tar over Nordisk tidsskrift for pedagogikk og kritikk
}

\author{
Ilmi Willbergh ${ }^{1}$ og Pål Aarsand ${ }^{2 \star}$ \\ ${ }^{1}$ Universitetet $i$ Agder, Norge; ${ }^{2}$ Norges teknisk-naturvitenskapelige universitet, Norge
}

Siden starten i 2015 har Nordisk tidsskrift for pedagogikk og kritikk utviklet seg til å bli en betydelig stemme i det pedagogiske fagfeltet i Norden. Når vi nå overtar ledelsen etter Maria Øksnes, er det med både ydmykhet og takknemlighet for den innsatsen hun og seksjonsredaktørene har lagt ned.

Vi ønsker å understreke viktigheten av kritikk i den pedagogiske forskningen. Vi ønsker forskning som stiller spørsmål ved det som tas for gitt, som problematiserer og reflekterer, og som viser åpenhet for nye tanker og ideer. Vi imøteser tekster som argumenterer for standpunkter og vurderinger av praksiser, ideologier, teorier og så videre. Denne våren publiserte vi tre inviterte bidrag fra Tone Kvernbekk, Karsten Tuft og Fritjof Sahlström, som fra helt ulike ståsteder belyser relasjonen mellom pedagogikk og kritikk. Bidragene viser hvordan kritikk og normativitet finnes som sentrale dimensjoner i den pedagogiske forskningen på ulike måter.

Nordisk tidsskrift for pedagogikk og kritikk skal være en diskusjonsarena for gode vitenskapelige fortellinger om pedagogiske praksiser. Et sentralt premiss for vårt arbeid er å akseptere pedagogikkens mangfoldighet og tverrvitenskapelighet. Pedagogikk kan ses som en vitenskapelig disiplin som studerer og produserer kunnskap om hvordan mennesket formes og utvikles i sosiale, kulturelle, historiske og materielle sammenhenger. En slik bred definisjon av pedagogikken åpner opp for forskning på alt fra læreplaner og lek i barnehagen, til utviklingen av kunnskapsorganisasjoner i arbeidslivet og ungdommers bruk av digitale spill. På denne måten forstår vi altså pedagogikken som fruktbar for å forstå fenomener ut over de som finnes i formelle utdanningsinstitusjoner.

Mangfold er også et stikkord for de vitenskapelige tilnærmingene vi ønsker at tidsskriftet skal representere. Vi ønsker filosofiske, historiske, sosiologiske og psykologiske perspektiver, men også mer eksplisitt uttalte tverrvitenskapelige perspektiver, slik som barndomsstudier, voksnes læring, kjønnsforskning og kulturstudier. 


\section{Willbergh \& P. Aarsand}

I tillegg er metodisk mangfold ønskelig. Kvalitative studier, kvantitative undersøkelser så vel som tekstanalyser bidrar til en økt forståelse av kompleksiteten i pedagogiske fenomener.

Nordisk tidsskrift for pedagogikk og kritikk har fra etableringen arbeidet med å få frem bidrag innen ulike sjangre. Klassiske vitenskapelige artikler har helt klart vært dominerende, og kommer til å være det fremover også, men vi ønsker i tillegg å slå et slag for å øke antallet vitenskapelige essays og bokmeldinger. Begge disse sjangrene bidrar til en kritisk og levende diskusjon innenfor det pedagogiske feltet. Mangfold, pluralisme og debatt ser vi som viktige faktorer i arbeidet med å forstå kompleksiteten i pedagogiske fenomener.

Det er viktig å påpeke at tidsskriftet har en nordisk profil. Dette betyr at vi ønsker bidrag fra hele Norden. I dag føres den vitenskapelige debatten innenfor pedagogikkfeltet i stor grad i engelskspråklige tidsskrifter. Et sentralt språkpolitisk standpunkt for Nordisk tidsskrift for pedagogikk og kritikk er at vi ønsker å publisere forskning også på svensk og dansk. Vi ser det som viktig at fagfeltet utvikler og bruker våre morsmål som profesjonelle verktøy i den pedagogiske debatten. Det å kunne sette ord på, beskrive, kritisere og diskutere pedagogiske praksiser på morsmålet er sentralt kanskje særlig i kommunikasjonen med studenter og andre aktører innenfor aktuelle praksisfelt. Samtidig må det poengteres at det engelske språket er en forutsetning for at alle de nordiske landene skal kunne delta i felles faglige diskusjoner.

Siden årtusenskiftet har pedagogisk forskning og praksis blitt utfordret på måter vi ikke har sett maken til i vår levetid. Utdanningspolitikken har i økende grad blitt internasjonal, hvilket har omkalfatret måten utdanning organiseres og styres på. Globale digitale kommunikasjonsformer forandrer sosiale og kulturelle mønstre, der forandringene skjer raskere enn før. Bioteknologi og kunstig intelligens konfronterer vår tradisjonelle oppfatning av hva som er menneske, hva som er natur og hva som er kultur. Samtidig rokkes det ved tilliten til vitenskapelig kunnskap og de tradisjonelle profesjoners autoritet. Alle disse utfordringene griper inn i og påvirker pedagogisk forskning og praksis. Derfor mener vi at det er viktig at pedagogikken lever videre som et kritisk fagfelt.

Vår ambisjon er at Nordisk tidsskrift for pedagogikk og kritikk skal sette viktige utfordringer på agendaen.

August 2021

Pål Aarsand og Ilmi Willbergh 